\title{
Hospice and Palliative Medicine in the Republic of Poland, Romania \& the Slovak Republic: Policy Implementation, Medical Economics, \& Clinical Outcomes
}

\section{Owens (Meagan Owens)ํ. D. J. West (Daniel J. West)²}

${ }^{1}$ MHA Program University of Scranton, Scranton, PA, USA

${ }^{2}$ Department of Health Administration and Human Resources, University of Scranton, USA

\section{E-mail address:}

meagan.owens@scranton.edu

\section{Reprint address:}

Meagan Owens

MHA Program University of Scranton, Scranton, PA, U.S.

Department of Health Administration and Human Resources

University of Scranton

Scranton, PA. 18510

USA

Source: Clinical Social Work and Health Intervention Pages: $93-100$
Volume: 10

Issue: 2

\section{Reviewers:}

Eva Grey

St. Elisabeth University of Health and Social Work, Bratislava, Slovakia Vlastimil Kozon

Allgemeines Krankenhaus - Medizinischer Universitätscampus, Vienna, Austria

\section{Key words:}

Hospice. Palliative Medicine. Economic. Policy Implementation.

\section{Publisher:}

International Society of Applied Preventive Medicine i-gap

CSWHI 2019; 10(2): 93 - 100; DOI 10.22359/cswhi_10_2_12 @ 2019 Clinical Social Work and Health Intervention

\section{Abstract:}

Objective: The aim of this research is to compare the current state of hospice and palliative medicine in The Republic of Poland, Romania, and the Slovak Republic. 
Design: The paper is a secondary source literature review.

Results: Hospice and palliative medicine are well integrated into each national healthcare system, but proper funding is needed in order to continue expanding this form of care and reach all patients in need.

Conclusion: Since the 1990s, Poland, Romania, and the Slovak Republic have made significant strides in developing hospice and palliative medicine and integrating this care into their national healthcare systems. Opportunities for future development include creating models for funding through the national healthcare systems and expanding homebased palliative care modalities.

\section{Development}

\section{Polish Palliative Care}

The term "hospice-palliative care" is commonly used in Poland, originating from the necessity for special care of terminally ill cancer patients (Schmidlin, 2012). The beginning of palliative care in Poland is associated with the democratic opposition in the 1980s. Earlier in 1978, Dame Cicely Saunders visited Gdansk, Warsaw, and Krakow, supporting an organization of palliative care in Poland. By 1981 palliative care societies, which had previously been only informal, became formal and officially registered. Both institutional and homebased hospice care existed in all larger cities in Poland in the 1990s (Swietlik \& Doboszynska, 2009).

In Poland, many of the palliative care organizations are run by religious organizations, considering the Polish palliative care movement began primarily as a religious undertaking. There are also nearly 200 institutions within the national health care service created by civic associations. Though they still have many volunteers, they have evolved from fully volunteer hospices in the beginning (Schmidlin, 2012). In 1991, National Forum of the Hospice Movement was founded, and in 1998, Poland officially offered a specialization in palliative care for both physicians and nurses (Swietlik \&

Doboszynska, 2009). According to Dr. Stephen Connor (personal communication, April 3, 2017), the Executive Director of the Worldwide Hospice Palliative Care Alliance, today Poland is one of the model nations for palliative care development in Central Eastern Europe.

\section{Romanian Palliative Care}

In Romania, the concept of palliative care arose in the late 1980s from a need to care for HIV/AIDS patients, specifically children (Mosoiu, Andrews, Perolls, 2000). As the result of a heavily regulated system, gaining access to opioids was extremely difficult, and Romania's annual morphine consumption was among the lowest in Eastern Europe (Institute of Medicine, 2007). Since then, a number of developments have turned Romania into a regional leader in end-of-life care. The palliative care movement gained momentum in the late 1990s, with the support of a philanthropists from the United Kingdom, Graham Perolls. Through that support, the first home-based hospice in Romania, Hospice Casa Sperantei, opened in Brasov in 1992, covering an area with a population of 400,000 (Hospice Casa Sperantei Annual Report, 2015). 
Today Hospice Casa Sperantei has become a model institution, now replicated in other parts of Eastern Europe, while its funder, the Hospices of Hope, has helped establish partner organizations and hospice care programs across Romania and in the Central Eastern European Region (Hospice Casa Sperantei Annual Report, 2015). According to the Annual Report for 2015, during that year 3,498 children and adults received services free of charge. There were " 17,531 home visits, 849 hospice inpatients, and 4,867 received consultation from the outpatient clinic." Additionally, in Romania individuals can redirect $2 \%$ of their income tax to the care of patients with incurable illnesses. In 2015, “18,500 donors chose HOSPICE, redirecting a total of 301,000 euros to the organization. There is no cost to the donor."

\section{Slovak Republic Palliative Care}

In the Slovak Republic, palliative medicine was developed on the principles of pain management for the terminally ill, developing primarily in the 1990s. The term "hospice" first appeared in legislative documents in 2000, and the first hospice was Matky Terezy Hospice in Bardejovská Nová Ves, established in July 2003. Many other hospices followed after that, and by 2006 palliative care was adopted in multiple care settings such as outpatient departments, hospitals, hospice institutions, in the home setting. In 2014, eight hospice facilities had 154 beds, and 94 beds were in hospital-based palliative departments (Križanová \& Škripeková, 2015).

\section{Policy Implementation}

The most important, practical healthcare policy that affects the quality of palliative care in a country is its opioid access laws. Everything done in palliative medicine revolves around pain management. "Pain management opens the gate to bringing in all the rest that we know-the social, spiritual, cultural issues that are there," says Anne Merriman, founder of Hospice Africa. "With pain control, people can start to think again." (The Economist, 2010).

The World Health Organization (WHO) decreed that adequate pain control is an essential component of caring for cancer patients, and there is no other measure that can improve the quality of life of that population as much as palliative care (The Economist, 2010). In order to achieve quality pain control, the WHO and the International Association for Hospice and Palliative Care (IAHPC) have a published list of recommended opioid formularies, with the WHO recommending four formularies and the IAHPC recommending seven formularies. The chart below outlines the specific recommendations on opioid use.

\begin{tabular}{lll}
\hline & $\begin{array}{l}\text { WHO essential } \\
\text { medicine 2007 }\end{array}$ & $\begin{array}{l}\text { IAHPC } \\
2007\end{array}$ \\
\hline Codeine & $X$ & $X$ \\
\hline $\begin{array}{l}\text { Morphine, PO immediate release } \\
\text { (tablet or liquid) }\end{array}$ & $X$ & $X$ \\
\hline $\begin{array}{l}\text { Morphine, PO controlled release } \\
\text { Injectable morphine }\end{array}$ & $X$ & $X$ \\
\hline $\begin{array}{l}\text { Oxycodone, PO immediate release } \\
\text { Fentanyl, TD }\end{array}$ & $X$ \\
\hline $\begin{array}{l}\text { Methadone, PO immediate release } \\
\text { WHO, World Health Organization; IAHPC, International Association for Hospice } \\
\text { and Palliative Care; PO, oral; TD, transdermal. }\end{array}$ & $X$ \\
\hline
\end{tabular}

(Cherny N, Baselga J, de Conno, F, Radbruch L, 2010) 
All three countries provide access to all recommended medications, but this was not always the case.
Another aspect of opioid availability is how easily physicians can provide patients with the necessary medication, and regulations vary by country.

\begin{tabular}{|c|c|c|c|c|c|c|}
\cline { 2 - 7 } \multicolumn{1}{c|}{} & \multicolumn{2}{|c|}{$\begin{array}{r}\text { Regulations require patient } \\
\text { permit/registration to receive } \\
\text { opioid prescription }\end{array}$} & \multicolumn{3}{c|}{$\begin{array}{r}\text { Physicians need permit to } \\
\text { prescribe opioids }\end{array}$} \\
\cline { 2 - 7 } \multicolumn{1}{c|}{} & Out Patient & In Patient & Hospice & Oncologist & Family MD & Surgeon \\
\hline Poland & & & & & & \\
\hline Romania & & & & & & No data \\
\hline Slovakia & & & & & & \\
\hline
\end{tabular}

\begin{tabular}{|c|}
\hline No Permit Needed \\
\hline Permit Needed \\
\hline
\end{tabular}

(Cherny N, Baselga J, de Conno, F, Radbruch L, 2010)

In February 2002, Romania, because of its severe restrictions on access to opioids, was selected as a pilot for follow-up from a workshop run by the University of Wisconsin Pain and Policy Studies Group, which is part of the World Health Organization's European Office and the Open Society Institute (Mosoiu, D., et al., 2006). During the years of 2003 to 2005, in partnership with University of Wisconsin at Madison, the Ministry of Health and its Palliative Care Commission prepared revisions of Romania's national narcotics law and regulations. Their recommendations were adopted by the Romanian Parliament in November 2005, and the new law eliminating the regulatory barriers eased access to pain medication for dying patients (Institute of Medicine, 2007). These regulatory changes played a significant role in Romania becoming a regional leader in the provision of palliative care.
Not all physicians are able to prescribe opioid medications to their patients in all three countries. Currently, only Poland allows all physicians to prescribe opioid medications to their patients. In both Romania and the Slovak Republic, only oncologists, surgeons and some pain specialists can prescribe opioid medication. No family medicine physicians can prescribe opioids, and currently in the Slovak Republic, no palliative physicians can prescribe opioids (Cherny N, Baselga J, de Conno, F, Radbruch L, 2010). Additionally, Romania and the Slovak Republic require that most patients who are to receive the opioids register and receive a permit stating that they are indeed eligible to receive the medication. If a patient is an inpatient in a hospital, no permit is needed, but on an outpatient basis, permits are required, though steps have been taken to ensure that permit processes are not burdensome for patients. Poland has no such permitting process and any patient who 
has a prescription for an opioid may have the prescription filled. Additional regulations exist on the amount of opioid medication that may be prescribed at one time. Poland allows physicians to prescribe an unlimited number of days per opioid prescription. In Romania and Poland, each prescription is limited to a 30-day supply (Cherny N, Baselga J, de Conno, F, Radbruch L, 2010).

\section{Level of Integration}

Another aspect of hospice and palliative medicine policy in each country is how well palliative medicine is integrated into the national health care systems. The Worldwide Hospice and Palliative Care Alliance created a Global Atlas of Palliative Care at the End of Life (2014), and in this atlas the organization developed categories for how well palliative medicine is integrated into the mainstream service provision. Both Romania and Poland are at a $4 \mathrm{~b}$ (the highest level of integration), and in 2014 the Slovak Republic was re-categorized from a $3 \mathrm{~b}$ to a $4 \mathrm{a}$ (the second highest level of integration). Both Romania and Poland being at a $4 \mathrm{~b}$ means that palliative medicine is at an advanced state of integration into the mainstream service provision. This is because of the following facts about the country's palliative services:

- comprehensive provision of all types of palliative care by multiple service providers

- broad awareness of palliative care on the part of health professionals

- unrestricted availability of morphine and all other strong pain-relieving medicines

- substantial impact of palliative care upon policy, particularly public health policy

- existence of a national palliative care association

- (Worldwide Hospice and Palliative Care Alliance, 2014)

\section{Slovakia's category 4a means:}

- many hospices had opened in the country

- hospice beds were now available in hospitals and teaching hospitals

- palliative care being implemented into postgraduate education for physicians and undergraduate education for nurses

- a Chair of Palliative Medicine at Slovak Medical University had been established

- good availability of morphine

- national association of palliative care (Slovak Association of Hospice \& Palliative Care)

(Worldwide Hospice \& Palliative Care Alliance, 2014).

\section{Medical Economics}

As palliative medicine becomes further integrated into mainstream service provision, it becomes important to understand how much it will cost, and specifically how much it will cost to provide quality palliative care. With a limited amount of financial resources available to devote to palliative care, it is useful to develop a standardized costing framework. Studies of palliative care wards in Poland show that payments from the national health system cover only $60 \%$ of the costs incurred by the units (Ciałkowska-Rysz, 2016). In Slovakia hospices, $40-60 \%$ of the cost of inpatient palliative care is paid for by patients and families, as the health insurance companies do not consider hospices to be necessary medical facilities. And for outpatient care, patients must contribute to the cost of medications (Križanová \& Škripekov, 2015).

A 2014 study in the Journal of Pain and Symptom Management developed a costing framework for palliative care (Mosoiu, Dumitrescu, \& Connor 2014). Using Romania as a model, the authors developed 
cost analysis elements for palliative care providers in two different settings, the inpatient units and home-based palliative care. First, an interdisciplinary group of palliative care experts identified standards of quality palliative care delivery in the inpatient and home care settings. Surveys were conducted of government agencies and palliative care providers to identify payment practices and budgets for palliative care services. In the second phase, unit costs were defined and a costing framework was designed to measure inpatient and home-based palliative care unit costs. The final phase was advocacy for inclusion of the calculated costs into the national funding system. It was the author's intent that the framework could be applied to many countries (Mosoiu, Dumitrescu, \& Connor 2014).

Through the Romanian study, the significant economic benefit of home-based palliative care became evident as represented in the graph below: human resources and offers care to a larger number of patients. This demonstrates that with a finite amount of funding available in national health care systems, an investment in expanding home-based palliative care is of great economic value (Mosoiu, Dumitrescu, \& Connor 2014).

\section{Clinical Outcomes}

The most important aspect of hospice and palliative care is the impact it has on patient care and clinical outcomes. There is a direct, measurable change in the quality of care patients receive once they elect this form of treatment. As demonstrated by Mosoiu (2014), the average patient admitted to hospice services had 13.4 symptoms on admission. These were symptoms such as pain, nausea, anxiety, and fatigue due to disease progression and often the side effects of curative treatment the patient had undergone prior. By the time of death, the patient
Home Palliative Care Month of Care

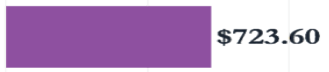

$\mathrm{O}$ 500 1000

(Mosoiu, Dumitrescu, \& Connor 2014)

Home care allows the patient to receive care in their preferred environment and to have greater independence and control of the care, in addition to involving the family in daily care with support from a specialized team. From an economic standpoint, home care involves less financial and had improved to only have an average of 5.4 symptoms. Additionally, the remaining symptoms were reduced in severity, with any pain being lower on a scale of $1-10$, and other symptoms being much less distressing, such as dry-mouth, which is often a side effect of medication (Mosoiu, D. 2014). 
In addition to improved symptom management, patients experience an improved quality of life. This is due in large part to the physical relief they experience, and also because many palliative care programs offer care at home, in a familiar environment for the patient. Caregivers are also less likely to experience depression and mental health issues after the death of their loved one (Mosoiu, D. 2014). An inter-disciplinary approach ensures the whole person is cared for, body, mind, and soul, which is beyond only managing a disease. And the interdisciplinary team also facilitates better decision-making as they are able to help align treatment with the patient's wishes and are involved in all care transitions providing a greater continuity of care and consistent follow-through on the plan of care (Mosoiu, D. 2014).

\section{Conclusion}

One of the unique and sacred aspects of palliative care is that there is only one chance to get it right. Patients only die one time. A daughter will lose her mother only one time, a husband will watch his wife die only once, and health care systems only have one chance to ensure that a patient's death is a good death. With the medicines and medical expertise available in the world today, no one should live in pain or distress until they die. Poland, Romania, and the Slovak Republic have undertaken significant work since the 1990 s to ensure that those with life-limiting illnesses in their country can die in comfortable dignity, fully living as many days as they have left.

\section{References}

1. BEEK $\mathrm{K} V$, WOITHA $\mathrm{K}$, AHMED N, MENTEN J, JASPERS B, ENGELS Y, HASSELAAR J (2013) Comparison of legislation, regulations and national health strategies for palliative care in seven European countries (results from the Europall research group): a descriptive study. $\mathrm{BMC}$ Health Services Research, 13, 275. http:// doi.org/10.1186/1472-6963-13-275 .

2. CHERNY N, BASELGA J, DE CONNO, F, RADBRUCH L (2010) Formulary availability and regulatory barriers to accessibility of opioids for cancer pain in Europe: a report from the ESMO/EAPC Opioid Policy Initiative. Annals of Oncology; 21 (3): 615-626. doi: 10.1093/annonc/mdp581.

3. CIALKOWSKA-RYSZ A D, POKROPSKA W, LUCZAK J, KAPTACZ A, STACHOWIAK A., HURICH K., KOSZELA M (2016) How much does care in palliative care wards cost in Poland? Archives of Medical Science : AMS, 12(2), 457-468. http:// doi.org/10.5114/aoms.2016.59272. Connor, S. (2017). Personal Communication. DUMITRESCU L (2006) Palliative care in Romania s.n. Retrieved from http://www.rug. nl/research/portal/files/2862670/05_c5.pdf.

4. ECONOMIST INTELLIGENCE UNIT (2010) The quality of death: Ranking endof-life care across the world. Retrieved from http:/graphics.eiu.com/upload/eb/qualityofdeath.pdf .

5. HOSPICE CASA SPERANTEI ANNUAL REPORT (2015) Retrieved from https:// www.hospice.ro/media/2016/08/HCS Raport-Anual-2015_online.pdf.

6. INSTITUTE OF MEDICINE (2007).Committee on cancer control in low- and middle-income countries.

7. NATIONAL ACADEMIES PRESS (US) Retrieved https://www.ncbi.nlm.nih.gov/ books/NBK54036/.

8. KRIZANOVA K, SKRIPEKOV A (2015) Palliative care in Slovakia has come a long way since the 1990s. European Journal of Palliative Care. 2015; 22(5). Retrieved from http://www.eapcnet.eu/Portals/0/Organization/Publications/European\%20Insights/ EJPC22(5)_ Insight.PDF .

9. MOSOIU D, ANDREWS C, PEROLLS G (2000) Palliative care in Romania. PalliatMed 2000; 14: 65-67. 
10. MOSOIU D, DUMITRESCU M, CONNOR S (2014) Developing a costing framework for palliative care services. Journal of Pain and Symptom Management 48(4). DOI: 10.1016/j.jpainsymman. 2013.11.017.

11. MOSOIU D (2014) Palliative care as response to suffering at end of life. DOI: 10.2478/ress- 2014-0118.

12. MOSOIU D et al (2006) Reform of drug control policy for palliative care in Romania. The Lancet. 67 (9528): $2110-2117$.

13. SAUNDERS C (1976) Care of the $d y$ ing: The problem of euthanasia. Nursing Times. 72(26), 1003-1005.

14. SCHMIDLIN E (2012) Hospice-palliative care in Poland: more reflections. European
Association forPalliative Care. Retrieved from https://eapcnet.wordpress.com/2012/07/25/ hospice-palliative-care-in-poland-more-reflections/.

15. SWIETLIK E, DOBOSZYNSKA A (2009) History and organization of palliative care in Poland.

16. JOURNAL OF CLINICAL ONCOLOGY (27). Retrieved http://meetinglibrary.asco. org/content/34810-65 .

17. WORLDWIDE HOSPICE AND PALLIATIVE CARE ALLIANCE (2014). Global atlas of palliative care at the end of life. Worldwide Palliative Care Alliance. Retrieved from http://www.who.int/nmh/Global_Atlas_of_Palliative_Care.pdf. 